\title{
On the Reasons for the Vexing CSP-CFP Relationship: Methodology, Control Variables, Stakeholder Groups, and Measures The Review of 63 Studies from 1990s
}

\author{
Gang $\mathrm{Fu}^{1} \&$ Mingwen Jia ${ }^{1}$ \\ ${ }^{1}$ College of Economics and Management, Sichuan Agricultural University, Chendu City, Sichuan, China \\ Correspondence: Gang Fu, College of Economics and Management, Sichuan Agricultural University, 211 \\ Huiming Road, Wenjian District, Chendu City, Sichuan 611130, China. Tel: 1-917-689-3577. E-mail: \\ fugang96@163.com
}

Received: February 24, 2012 Accepted: March 28, 2012 Online Published: June 16, 2012

doi:10.5539/ijbm.v7n12p130 URL: http://dx.doi.org/10.5539/ijbm.v7n12p130

The paper is funded by "Double-Support Plan" project from Sichuan Agricultural University.

\begin{abstract}
Prior studies on the relationship between corporate social performance and corporate financial performance are inconclusive. In the paper, we review 63 studies, and find (1) there are three methodology, which are empirical analysis, normative analysis and meta-analysis; (2) control variables, such as industry, size and risk, have been playing the important role in these studies; (3) different researchers discuss different stakeholder groups; (4) measures of both CSP and CFP are the complex phenomenon, and still uncertain. We assert that the variations of methodology, industries, control variables, stakeholder groups, and measures of both CSP and CFP should be responsible for the vexing relationship.
\end{abstract}

Keywords: Corporate Social Performance (CSP), Corporate Financial Performance (CFP), stakeholder group, control variable

\section{Introduction}

Investigating the correlation between corporate social performance and corporate financial performance has been a lively confrontation since Milton Friedman's $(1962,1970)$ challenge that "a corporation's social responsibility is to make a profit." Friedman's views added fire and intellectual challenge to the debate and triggered additional interest in either proving or disproving the relationship between social performance and financial performance (Griffin, Mahon, 1997). A few scholars asserted that "the only responsibility of a business is to its shareholders" (Locke, 1996), but numerous researchers viewed that the firm is not a simple economic organization, and can't neglect the survival condition.

The research on the link between CFP and CSP has traditionally involved two different empirical issues: First, the direction (if exists) of the causality; and second, the sign of those identified causal relationship (Peston and O'Bannon, 1997; Surroca and Tribo, 2005). Although many researchers have explored the empirical relationship between CSP and CFP, no definitive consensus exists (Griffin \& Mahon, 1997). the minority of researchers found only a negative relationship (Vance,1975; Davidson \& Worrell, 1988; Bromiley \& Marcus,1989; Jarrell \& Peltzman,1985; Pruitt \& Peterson,1986; Shane \& Spicer,1983; Strachan et al.1983; Wier, 1983; Makni et al. 2009; Giannarakis \& Theotokas, 2011); some researchers have found the contradictory results, which are the positive and inconclusive relationship (Fray \& Hock,1976; Anderson \& Frankle, 1980; Freedman \& Jaggi, 1982), or the positive and negative relationship (Chen \& Metcalf, 1980; Cochran \& Wood, 1984; Coffey \& Fryxell, 1991); the majority of researchers have found the positive relationship (Belkaoui, 1976; Bowman, 1978; Hart \& Ahuja, 1994; Orlitzky, Schmidt, Rynes, 2003; Recchetti, 2007; Mahoney, LaGore, Scazzero, 2008; McGuire, Sundgren, Schneeweis, 1988; Simpson, Kohers, 2002, et.). Therefore, the impression that 'in the aggregate, results are inconclusive' regarding any theoretical conclusions about the relationship between CSP and CFP has persisted until today (Orlitzky et al.2003).

Why does the relation between CSP and CFP seem so unclear and elusive? Griffin and Mahon (1997) have asserted some reasons for these contradictory results stem from conceptual, operationalization, and 
methodological differences in the definitions of social and financial performance (Wood, 1991). Similarly, Waddock and Graves (1997) have pointed out that one fundamental reason for the uncertainty about the relationship between CSP and CFP is the problem of measuring CSP. And Margolis and Walsh (2001) have noted concern over the methodology used in many of the studies. Despite these researches, the linkages between CSP and financial performance are still far from clear (Ullman, 1985). Ruf el. (2001) early asserted that research on the relationship between CSP and CFP has produced conflicting results. The conflicting findings are attributed to both theoretical and methodological issues. Reasons include: (1) lack of a theoretical foundation, (2) lack of a comprehensive systematic measure of CSP, (3) lack of rigorous methodology, (4) sample size and composition limitations, and (5) mismatch between social and financial variables. Similarly, Brammer and Millington (2008) expressed that the failure to reach a consensus on relation of CSP and CFP arises for a number of reasons as follows: (1) the conceptual determinants of CSP, and consequently the theoretical expectations of the CSP-CFP relationship; (2) severe difficulties encountered in measuring CSP; (3) the lack of consensus in the literature reflects the very broad rang of measures of CFP employed in existing studies.

However, it is important to investigate the real relationship between corporate social performance and corporate financial performance. The clear linkage contributes to researchers' work progressively and stakeholder's making-decision. This review of literature may help researchers find out the present status and reasons for the vexing relationship. In this paper, we will specifically focus on the previous 63 studies (see appendix). The remainder of the paper is organized as follows. In the next section, we review methodology, industries and control variables. The third and the fourth respectively review stakeholder groups, measures of CSP and CFP. The last section includes conclusions and future research.

\section{Different Methodology, Industries and Control Variables}

\subsection{Different Methodology}

The research conclusions on the relationship of CSP and CFP are inconsistency or contradictory, which has been recognized by most researchers. Some researchers (Cochran \& Wood, 1984; Ullmann, 1985; Woddock \& Mahon, 1991) argue that methodological differences are one reason of inconclusive relationship between CSP and CFP. "The methodological limitations of prior studies obscure the true association between CSP and CFP thereby resulting in inconsistent results" (Darren et al. 2009). In the analysis we divide the methodology into three types: empirical analysis (EA), normative analysis (NA) and meta-analysis (MA). Of 63 studies (see Table 1), 41 studies use empirical analysis method, such as Anderson \& Olsen (2011), Gromark \& Melin (2011), Chang (2010), Waddock \& Graves (1997), Griffin \& Mahon (1997), Phillips (1999), McWilliams and Siegel (2000), Surroca \& Tribo (2005) etc. 16 studies adopt normative analysis method, such as Pava \& Krausz (1996), Johnson (2003), William (2010), Orlitzky (2002), Peloza (2006), Woller (2007). And there are 6 meta-analysis articles, such as Orlitzky et al. (2007), Orlitzky (2001, 2011), Moore \& Robson (2002), Wu (2006), Sefa \& Bradleyr (1999).

Table 1. Methodology of the relationship between CSP and CFP

\begin{tabular}{lcccc}
\hline Analysis method & $E A$ & $N A$ & $M A$ & Total \\
\hline Number of study & 41 & 16 & 6 & 63 \\
\hline
\end{tabular}

\subsection{Different Industries}

The different industry's level may affect firm performance, as competition in a highly-differentiated industry is unlikely to be price-based and, thus, is likely to be profitable for all concerned (Porter, 1980, 1986). Therefore, some industries lend themselves to higher levels of differentiation than others, and industry level factors would impact performance (McGahan and Porter, 1997). Given the evidence that suggests that firms do better in indusries in which companies allocate more resource to differentiation activities, it is reasonable to expect that industry differentiation will impact firm performance (Clyde \& Sandra, 2008).

Therefore, numerous researchers take industry factor into account in process of investigating the relationship of CSP-CFP, and a few researchers especially have researched a certain industry. For example, Moore \& Robson (2002), Moore (2001) investigate supermarket industry in the U.K., Barnett \& Salomon $(2002,2006)$ focus on socially responsible investment funds, Simpson \& Kohers (2002), Woller (2007) research banking industy,and Jackson \& Parsa (2009) perform a typology for service industries. Most researchers have performed the cross-industry research, in which they take the industry factor as a key control variable. Of 41 empirical 
analysises, 22 studies apply industry as control variable.

\subsection{Different Control Variables}

In prior researches, most of articles showed that CFP is the determinant of CSP (Margolis, Walsh, 2003; Pava, Krausz, 1996), and the causality exists between CSP and CFP. However, many researchers have identified a number of variables believed to impact how a firm's social performance relates to its financial performance (Andersen \& Dejoy, 2011). Callan and Thomas (2009) found that control variables must be properly specified to avoid bias and that some measures are related to CFP. Using appropriate control variables is crucial to obtaining reliable results, as pointed out repeatedly by previous research (Callan, Thomas, 2009); so many researchers apply different control variables to investigate the relationship between CSP and CFP. Of 41 empirical studies, control variables include firm size, risk, industry $\mathrm{R} \& \mathrm{D}$ expenses, advertising expenses, average age of corporate asset and others (see Table 2). In control variable categories, size, risk and industry are used much frequently, respectively being $73 \%, 56 \%$ and $54 \%$ of total studies. Different researchers use different indicators for same control variable catalogue. For example, the measures of firm size have total sales, total assets, the number of employees, the log of assets and average turnover over the period (McWilliams and Siegel,2000; Mahoney and Roberts, 2007; Johnson and Greening, 1994; Peter and Sarah, 1998); the measures of risk include Debt/Total Asset, financial leverage, Beta, long-term debt to total assets, average gearing over the period, an interest coverage ratio, quick ratio, cash ratio, P/E and MV/BV (Gerwin et al. 2008; Jordi, Josep, 2005; McWilliams, Siegel, 2000; Waddock, Graves, 1997); the measures of industry refer to Standard Industry Classification Code, dummy variable (1 for manufacturing, 0 for non-manu.) (McWilliams, Siegel, 2000; Bernadette, Krishnamurty, Robert, 2001; Anis, Belaid, Kamel, 2011.et.); the measures of R \& D expenses refer to R\&D expenditures to sales, amount of R\&D expenses (McWilliams, Siegel, 2000; Margaret, John, 2011. et.); the measures of advertising expenses include the amount of advertising expenses and the ratio of advertising expense to sales (McWilliams, Siegel, 2000; Stephen, Andrew, 2008. el.); firm age is the time period of incorporation); and other measures are complex, such as type of ownership, country, year, capital expenditure, listing in stock exchanges, percent stock, percent preferred, the level of pollution emissions, dividend ratio (Supriti, Damodar, 2010; Mahoney, Roberts, 2007.et.). The empirical studies have consistently identified size, risk and industry as factors which affect the CSP-CFP relationship (Callan and Thomas, 2009; Magolis and Walsh, 2003; Ulllman, 1985). As mentioned before, we find that firm size was one of the first variables identified as being a necessary control variable when examining the relationship between CSP and CFP. Similarly, risk and industry were identified as important control variables.

Table 2. Categories and number of control variables

\begin{tabular}{lccccccc}
\hline Control variables & $\begin{array}{c}\text { Firm } \\
\text { size }\end{array}$ & Risk & Industry & $\begin{array}{c}\text { R\&D } \\
\text { expenses }\end{array}$ & $\begin{array}{c}\text { Advertising } \\
\text { expenses }\end{array}$ & $\begin{array}{c}\text { Firm } \\
\text { age }\end{array}$ & Others \\
\hline Number of studies & 30 & 23 & 22 & 10 & 6 & 3 & 9 \\
\hline
\end{tabular}

\section{Various Stakeholder Groups}

How to measure or reflect CSP relates to the internal elements of CSP in the process of examining the CSP-CFP relationship. As Surroca, Tribo and Waddock (2010) conceptualize CSP as the broad array of strategies and operating practices that a company develops in its efforts to deal with and create relationships with its numerous stakeholders and the natural environment (Waddock, 2004),the stakeholder related to CSP is not single. CSP should reflect the outcomes and levels of actions activated by stakeholders, who are stakeholder groups, hehaviors and environment. After reviewing 63 studies, we divide them into the following categories. The first category is based on consumers, which mostly relate with product quality, diversity, product safety, quality of services, innovativeness, alcohol, tobacco, gambling and nuclear power (Preston, O'Bannon, 1997; Mahoney, Roberts, 2007; Moore, 2001, etc.). The second category is based on government, community or military, such as governments, community investment, community relations, community and society, defense/weapons, military contracting( Brik, Rettab, Mellahi, 2011; Andersen and Dejoy, 2011; Surroca, Tribo, 2005; Fauzi, 2009; Baron, Harjoto and Hoje Jo, 2011,et.). The third category is based on employee, such as employees, human right, labor relations, ability to attractldevelop and keep talented people (Fauzi et al. 2007; Laan et al. 2008; Waddock and Graves, 1997, et.). The fourth type is based on shareholder or investor (Moore, 2001; Brik et al, 2011; Laan et al. 2008; May, Khare, 2008). The fifth type is based on internal management or governance, such as governance, quality of management, wise use of corporate assets, ownership in other companies, South Africa investments, 
financial soundness, on-U.S. operations (Peter and Sarah, 1998; Andersen and Dejoy, 2011; Fauzi and Mahoney, Rahman, 2007; May and Khare, 2008; Anderson and Olsen, 2011; Nelling and Webb, 2009, et.). The sixth is based on society and environment, including responsibility to the community and the environment, natural environment, philanthropic donation, NGOs, contribution to society (Mishra, Suar, 2010; Clyde, Hull and Rothenberg, 2011; Surroca, Tribo and Waddock, 2010; Brammer and Millington, 2008, et.). The seventh is based on suppliers (Mishra and Suar, 2010; Peters and Mullen, 2009; Brik et al.2011). The eighth type is based on women's and minority issues (Ruf et al.2001; Waddock and Graves, 1997; Nelling and Webb, 2009, et.); The last angle is based on others, such as fairness (Choi et al.2010), other concerning compensation (Fauzi et al. 2007), animal testing (Barnett and Salomon, 2002). In nine groups, researchers often refer to these stakeholder groups, such as employees, communities and consumers, and environment. Of 63 studies, respectively 33 studies, 30 studies, 28 studies and 35 studies refer to communities, consumers (products), employees and environment. Otherwise, few researchers just refer to single stakeholder group. For example, Simpson \& Kohers (2002) just take community relations into account, Schuler \& Cording (2006) and Gromark \& Melin (2011) just think of consumers, and Brammer and Millington (2008) only concern philanthropic donation. In fact, stakeholders considered by numerous researchers are over two categories.Especially, Laan et al. (2008) divide stakeholders into two levels, which are primary stakeholders and secondary stakeholders. The former include employees, consumers and environment, and the latter include communities, diversity, investors and human right.

\section{Various Measures of CSP and CFP}

\subsection{Measures of CSP}

"CSP is a complex phenomenon" (Griffin, 2000). Past studies on CSP have been usually criticized for using inappropriate measure of CSP (Mishra and Suar, 2010). Piror researchers have adopted various proxy measures to assess CSP: (1) one-dimensional surrogate measures, such as reputation ranking of companies on pollution control performance (Freedman and Jaggi, 1982), (2) Moskowitz's social responsibility ratings (Moskowitz, 1972), (3) Fortune corporate reputation index (McGuire et al., 1988), and (4) KLD index (Kinder et al., 2005; Ruf et al., 2001; Waddock and Graves, 1997). These measures have been criticized for their inability to incorporate stakeholders' issues (1985; Ullman, 1985).

The measures of CSP have three categories, which are one-dimension single index, multidimensional comprehensive index, and multiple range indexes. In the samples, few studies use one-dimension single index and multiple range indexes to measure CSP. For example, Stephen Brammer and Andrew Millington (2008) use an special element of CSP, charitable donation, to investigate the link of CSP and CFP; Phillips (1999) apply two traditional variables, median household income (INC) and number of Medicare patients days as a percente of patients days (MED) to research how social responsibility drive long-term financial performance of not-for-profit hospitals.

CSP is a multidimensional construct (Griffin, 2000), with behaviors ranging across a wide rariety of inputs, internal behaviors or processes and outputs (Carroll, 1979; Waddock and Graves, 1997)), and each dimension has multiple variables and multiple operationalizations (Griffin, 2000). In the past twenty years, numerous researchers used multidimensional comprehensive index to measure CSP, such as the KLD index, the Fortune reputation rating, the Toxics Release Inventory (TRI), the composite CSP score, Dow Jones Sustainability Indexes (DJSI).

Among 41 empirical studies, the composite CSP score are used more frequently than others, and 24 studies apply the category to measure CSP ( Tang et al.2011; Gromark, Melin, 2011; Choi et al., 2010; Fauzi, 2009; May, Khare, 2008; Fauzi et al. 2007). Secondly, 14 studies have used the KLD index (McWilliams \& Siegel, 2000; Johnson, Greening, 1994; Waddock \& Graves, 1997; Harrison, Coombs, 2006; Callan, Thomas, 2009, et.). The TRI (Griffin, Mahon, 1997), the Fortune reputation rating (Peter, Sarah, 1998) and the DJSI (Lee, Faff, Kim, 2009) is used respectively for 1 study.

\subsection{Measures of CFP}

Corporate financial performance is "a subjective measure of how well a firm can use assets from its primary mode of business and generate revenues". There are a number of indicators to measure CFP, because researchers having different angles choose the indictators with various creterior. Orlitzky et al. (2003) assert that different CFP and CSP subsets employ different measurement strategies, which lead to systematically different effect sizes. There are three broad subdivisions of CFP, which are market-based, accounting-based, and perceptual measures (Orlitzky et al.2003). Firstly, market-based measures, such as price per share, reflect tha notion that shareholders are a primary stakeholder group whose satisfaction determines the company's fate (Cochran and Wood, 1984). Secondly, accounting-based indicators, such as the firm's ROA, ROE, and EPS, capture a firm's 
internal efficiency in some ways (Cochran and Wood, 1984). Lastly, perceptual measures ask survey respondents to provide subjective estimates of, for instance, the firm's 'soundness of financial position', 'wise use of coporate assets', or 'financial goal achievement relative to competitors' (Conine and Madden, 1987; Reimann, 1975; Wartick, 1988).

The application of CFP measures used by researchers shows the characteristics of diversification. Some researchers use individual indicator,such as ROA (Mahone et al., 2008; Peters, Mullen, 2009; Tang et al. 2011), accounting profit (McWilliams and Siegel, 2000), market value/book value (Andersen and Dejoy, 2011; Baron et al. 2011), ROS (Peter and Sarah, 1998), debt-to-total asset ratio (Harrison and Coombs, 2006), market value-added (MVA) (Surroca and Tribo, 2005), free cash flow (Phllips, 1999), Tobin's Q (Dugar et al. 2011; Surroca et al. 2010), EBITA (Gromark and Melin, 2011; Brammer and Millington, 2008), operating income (Andersen, 2010), ROE (May, Khare, 2008). However, most researchers adopt more one indicator to reflect CFP. For example, Griffin \& Mahon (1997) measure CFP with ROE, ROA, total asset and five year's ROS; Preston and O' Bannon (1997) use ROE, ROA and ROI; Ruf et al. (2001) have used the growth of ROS, ROE and ROS; Brik, Rettab and Mellahi (2011) have used the growth of ROS, the growth of profit, ROA and ROI et al.. Of 41 empirical studies, there are 18 studies with individual indicator, 23 studies with two indicators or more. ROA, the most common index, is used by 21 studies. Accordingly, there are 15 studies with ROE, 7 studies with ROS, 5 studies with Tobin's Q, and 4 studies with MV/BV. Other indicators, such as P/E, EPS, annual return, total assets, turnover, Treynor Ratio, Sharpe measure, Jensen's alpha, are used less. Otherwise, most of researchers don't classify the measure of CFP except for Johnson \& Greening (1994) et al.

\section{Conclusions and Future Research}

The relation between a company's financial performance and its corporate social performance has been a topic of interest and controversy for more than half of a century (Preston and O'Bannon, 1997), and serious empirical research on the relationship between social and financial performance indicators has been going on for over 30 years. In spite of long research history, the correlation between corporate social and financial performance has not been fully established (Preston, 1997), and the nature of the relationship remains unresolved (Andersen and Olsen, 2011). After reviewing 63 studies, we can find the followings: (1) in the previous studies, there are three methodologies, which are empirical analysis, normative analysis and meta-analysis; (2) a number of factors would influence their relationship, so control variables have been playing the important role in these studies, such as industry, size and risk; (3) previous researchers discussed different stakeholder groups; (4) measures of both CSP and CFP are extremely complex, and still uncertain. The variations of methodology, industries, control variables, stakeholder groups, and measures of both CSP and CFP result in the vexing relationship. Therefore, future researchers should consider the certain stakeholders, such as government, consumers, employees, social welfare, natural environment and suppliers, then adopt the appropriate methodology to investigate the CSP-CFP relationship in different industries, with special control variables, such as the log of total assets, the ratio of national ownership's equities, the leverage, and with financial measures based on both market and accounting, such ROA and Tobin's Q.

\section{References}

Donna J. Wood. (1991a). Corporate Social Performance Revisited. Academy of Management Review, 16(4), 691-718.

Donna J. Wood. (1991b). Social Issues in Management Theory and Research in Corporate Social Performance. Journal of Management, 17(2), 383-406. http://dx.doi.org/10.1177/014920639101700206

Jeffrey S. H., \& Joseph E. C. (2006). Financial leverage and social performance. Academy of Management, F1-F6.

Jordi S., \& Josep A. T. (2005). The corporate social and financial performance relationship: what's the ultimate determinant?. Academy of Management, E1-E6.

Lois M., \& Robin W. R. (2007). Corporate social performance, financial performance and institutional ownership in Canadian firms. Accounting Forum, 31, 233-253. http://dx.doi.org/10.1016/j.accfor.2007.05.001

Lois M., William L., \& Joseph A. S. (2008). Corporate social performance, financial performance for firms that Restate earnings. Issues in Social and Environmental Accounting, 2(1), 104-130.

Marc O. (2001). Does Firm Size Confound the Relationship between Corporate Social Performance and Firm Financial Performance? Journal of Business Ethics, 33, 167-180. http://dx.doi.org/10.1023/A:1017516826427 
Marc O. (2005). Social responsibility and financial performance: trade-off or virtuous circle?. University Auckland Business Review, 38-44.

Marc O., Frank L. S., \& Sara L. R. (2003). Corporate Social and Financail Performance: A meta-analysis. Organization Studies, 24(3), 403-441. http://dx.doi.org/10.1177/0170840603024003910

Margaret L. A., \& Lori O. (2011). Corporate social and financial performance: a canonical correlation analysis. Academy of Accounting and Financial Studies Journal, 15(2), 17-37.

Michael L. B., \& Robert M. S. (2006). Beyond dichotomy: the curvilinear relationship between social responsibility and financial performance. Strategic Management Journal, 27, 1101-1122. http://dx.doi.org/10.1002/smj.557

Richard P., \& Michael R. M. (2009). Some evidence of the cumulative effects of corporate social responsibility on financial performance. The Journal of Global Business Issues, 3(1), 1-14.

Rim M., Claude F., \& Francois B. (2009). Causality between corporate social performance and financial performance: evidence from Canadian firms. Journal of Business Ethics, 89, 409-422. http://dx.doi.org/10.1007/s10551-008-0007-7

Robert N., \& Philip L. C. (2008). Corporate social responsibility, corporate governance, and financial performance: Lessons from finance. Business Horizons, 51, 535-540. http://dx.doi.org/10.1016/j.bushor.2008.07.002

W. Gary S., \& Theodor K. (2002). The link between corporate social and financial performance: evidence from the banking industry. Journal of Business Ethics, 35, 97-109. http://dx.doi.org/10.1023/A:1013082525900

William S. C. (2010). Social network and corporate financial performance: conceptual framework of board composition and corporate social responsibility. International Journal of Business and Management, 5(6), 92-97.

Zhi T., Clyde E. H., \& Sandra R. (2011). How corporate social responsibility is pursued affects firm financial performance. Academy of Management Meeting.

\section{Appendix}

The literature on relationship of CSP and CFP since 1990s

\begin{tabular}{llc}
\hline Writers & Journal or Meeting & Year \\
\hline From 1990 to 1999 (8 aticles) & & \\
Moses L. Pava, Joshua Krausz & Journal of Business Ethics & 1996 \\
Jennifer J. Griffin, John F. Mahon & BUSINESS\&SOCIETY & 1997 \\
Lee E. Preston, Douglas P. O’Bannon & BUSINESS\&SOCIETY & 1997 \\
Ronald M. Roman, Sefa Hayibor, Bradley R. Agle & BUSINESS\&SOCIETY & 1999 \\
Janet F. Phillips & Journal of Health Care Finance & 1999 \\
Richard A. Johnson, DaniealW. Greening & ACADEMY OF MANAGEMENT & 1994 \\
Peter A.Stanwick,Sarah D.Stanwick & Journal of Business Ethics & 1998 \\
Sandra A. Waddock, Samuel B. Graves & Strategic Management Journal & 1997 \\
From 2000 to 2009 (39 articles) & & \\
Marc Orlitzky, Frank L.Schmidt, Sara L.Rynes & Organization Studies & 2003 \\
Abagail McWilliams, Donald Siegel & Strategic Management Journal & 2000 \\
Homer H.Johnson & Business Horizons & 2003 \\
Lois Mahoney,Robin W. Roberts & Accounting Forum & 2007 \\
Marc Orlitzky & Journal of Business Ethics & 2001 \\
Geoff Moore and Andy Robson & Business Ethics: A European Review & 2002 \\
Michael L.Barnett and Robert M. Salomon & Academy of Management & 2002 \\
Benjamin A. Neville, Simon J. Bell, Bulent Menguc & European Journal of Marketing & 2005 \\
W. Gary Simpson, Theodor Kohers & Journal of Business Ethics & 2002 \\
Geoff Moore & Journal of Business Ethics & 2001 \\
Bernadette M. Ruf, Krishnamurty Muralidhar, & Journal of Business Ethics & 2001 \\
\hline
\end{tabular}


Robert M. Brown,Jay J. Janney, Karen Paul

Marc Orlitzky

Jordi Surroca, Josep A. Tribo

Meng-Ling Wu

John Peloza

Douglas A. Schuler, Margaret Cording

Michael L.Barnett and Robert M. Salomon

Leonardo Becchetti

Jeffrey S. Harrison, Joseph E. Coombs

Gary Woller

Gerwin Van der Laan, Haans Van Ees, Arjen Van

Witteloostuijn

John Peloza and Lisa Papania

Jean-Pascal Gond, Guido Palazzo

Pieter van Beurden, Tobias Gossling

Jonas Nilsson

Stephen Brammer and Andrew millington

Hasan Fauzi, Lois S. Mahoney,Azhar Abdul Rahman

Peter May, Anshuman Khare

Richard Peters,Michael R.Mullen

Edward Nelling, Elizabeth Webb

Scott J.Callan,Janet M. Thomas

Lois Mahoney,William LaGore,Joseph A. Scazzero

Darren D. Lee, Robert W. Faff, Kim Langfield-Smith

Rim Makni, Claude Francoeur, Francois Bellavance

Hasan Fauzi

Leonard A. Jackson, H. G. Parsa

Hasan Fauzi

Robert Neal, Philip L.Cochran

Clyde, Eirikur Hull and Sandra Rothenberg

From 2010 to 2011 (16 articles)

Anis Ben Brik,Belaid Rettab,Kamel Mellahi

Margaret L. Andersen, John S. Dejoy

Roberto Garcia-Gastro, Miguel A. Arino, Miguel A.

Canela
University Auckland Business Review 2005

Academy of Management 2005

The Journal of American Academy of 2006

Business

California Management Review 2006

Academy of Management Review 2006

Strategic Management Journal 2006

Finance \& The Common Good/Bien 2007

Commun

Academy of Management Best Conference 2006

Paper

ESR Review 2007

Journal of Business Ethics 2008

Corporate Reputation Review 2008

Academy of Management Annual Meeting 2008

Proceedings

Journal of Business Ethics 2008

Journal of Business Ethics 2008

Strategic Management Journal 2008

Issues in Social and Environmental 2007

Accounting

Journal of Environmental Assessment 2008

Policy and Management

The Journal of Global Business Issues 2009

Review of Quantitative Finance \& 2009

Accounting

Corporate Social Responsibility and 2009

Environmental Management

Issues in Social and Environmental 2008

Accounting

Australian Journal of Management 2009

Journal of Business Ethics 2009

Issues in Social and Environmental 2009

Accounting

International Journal of Business Insight \& 2009

Transformation

Globsyn Management Journal 2009

Business Horizons 2008

Strategic Management Journal 2008

Journal of Business Ethics 2011

Business and Society Review 2011

Journal of Business Ethics 2010 


\begin{tabular}{llc}
\hline Jordi Surroca, Josep A. Tribo, Sandra Waddock & Strategic Management Journal & 2010 \\
Jong-Seo Choi,Young-Min Kwak, Chongwoo Choe & Australian Journal of Management & 2010 \\
$\begin{array}{l}\text { David J. Flanagan, K. C. O'Shaughnessy, Timothy } \\
\text { B.Palmer }\end{array}$ & Corporate Reputation Review & 2011 \\
Margaret L. Andersen & & \\
& The Academy of Accounting and Financial & 2010 \\
William S. Chang & Studies & \\
& International Journal of Business and & 2010 \\
Pushpika Vishwanathan & Management & \\
Kranti Dugar,Brian T.Engelland,Robert S. Moore & Academy of Management Annual Meeting & 2010 \\
Johan Gromark, Frans Melin & Society for Marketing Advances & 2010 \\
Marc Orlitzky & Journal of Brand Management & 2011 \\
Margaret L. Anderson, Lori Olsen & Business Ethics Quarterly & 2011 \\
& Academy of Accounting and Financial & 2011 \\
Zhi Tang,Clyde Eirikur Hull, Sandra Rothenberg & Studies Journal & \\
David P. Baron, Maretno Agus Harjoto, and Hoje Jo & Academy of Management Annual Meeting & 2011 \\
Supriti Mishra, Damodar Suar & Business and Politics & 2011 \\
\hline
\end{tabular}

Resource: EBSCO host database 